\title{
WIDYA BIOLOGI \\ PENGARUH PUPUK TRICHODERMA SP. DENGAN MEDIA TUMBUH \\ BERBEDA TERHADAP PERTUMBUHAN VEGETATIF TANAMAN CABAI MERAH BESAR (Capsicum Frutescens L.)
}

\section{(THE EFFECTS OF TRICHODERMA SP. FERTILIZER WITH DIFFERENT GROWING MIDIA ON THE VEGETATIVE GROWTH OF CHILI PLANT (Capsicum Frutescens L.)}

\author{
I Wayan Suanda ${ }^{1}$ \\ ${ }^{1}$ Proram Studidi Pendidikan Biologi Fakultas Pendidikan MIPA IKIP PGRI Bali, \\ Indonesia \\ Email: suandawayan65@gmail.com
}

\begin{abstract}
This research aimed to find out the effects of Trichoderma sp. fertilizers with different growing media on the vegetative growth of chili plants and to find out the best growing media to make it grow optimally. This research was conducted in the Biologi Laboratory at FPMIPA IKIP PGRI Bali from April to June, 2018. The research was done in several growing media; treatmen P0 (without the Trichoderma sp. fertilizer), P1 (Trichoderma sp. fertilizer from taro media), P2 (Trichoderma sp. fertilizer from cassava media), P3 (Trichoderma sp. fertilizer from sweet potato media), P4 (Trichoderma sp. fertilizer from corn media), P5 (Trichoderma sp. fertilizer from potato media). These treatments were repeated four times each. The population in this study were all chili pepper seeds of F1 Megatop variety with a total of 100 plants and a sample of 72 plant that were three weeks old. Each group contained of three chili plants. The data collected in this study were about the height and number of leaves on the chili plants. The data were analyzed using the analysis o variance (ANOVA) with $\mathrm{F}$ test and a 5\% significance level followed by the LSD test.Based on the analysis, there are several effects of Trichoderma sp. fertilizer with different growing media on the vegetative growth of chili plants. The results showed that treatment $\mathrm{P} 4$ (Trichoderma sp. fertilizer from corn media) have the most effective and optimal effects on the chili plants.
\end{abstract}

Keywords: Trichoderma sp., growing media, vegetative growth

\begin{abstract}
ABSTRAK
Penelitian ini bertujuan untuk mengetahui pengaruh pupuk Trichoderma sp. dari media yang berbeda terhadap pertumbuhan vegetatif tanaman cabai dan untuk mengetahuni pada jenis media tumbuh yang dapat memberikan petumbuhan yang paling optimal. Penelitian ini dilaksanakan di laboratorium Biologi FPMIPA IKIP PGRI Bali dari bulan April sampai bulan Juni 2018. Penelitian dengan perlakuan P0 (tanpa pupuk Trichoderma sp.), P1 (pupuk Trichoderma sp. dari media talas), P2 (pupuk Trichoderma sp. dari media singkong), P3 (pupuk Trichoderma sp. dari ketela malem), P4 (pupuk Trichoderma sp. dari media jagung), P5 (pupuk Trichoderma sp. dari media kentang) yang diulang masing-masing sebanyak empat kali. Populasi dalam penelitian ini adalah seluruh bibit cabai merah besar varietas Megatop F1 dengan jumlah 100 tanaman dan sampel sebanyak 72 tanaman yang telah berumur 3 minggu dimana setiap kelompok
\end{abstract}




\section{WIDYA BIOLOGI}

berisi 3 tanaman cabai rawit. Data yang dikumpulkan dalam penelitian ini adalah data tentang tinggi dan jumlah daun tanaman cabai rawit. Data yang diperoleh dalam penelitian ini dianalisis dengan menggunakan analisis varian (ANAVA) dengan uji F dan taraf signifikansi 5\% yang dilanjutkan dengan uji BNT. Berdasarkan hasil analisis ada pengaruh pupuk Trichoderma sp. dari media tumbuh yang berbeda terhadap pertumbuhan vegetatif tanaman cabai besar. Hasil analisis yang memberikan pengaruh paling efektif dan pertumbuhan yang paling optimal diperoleh pada perlakuan P4 (Trichoderma sp. dari media jagung).

Kata kunci : Trichoderma sp., media tumbuh, pertumbuhan vegetatif

\section{PENDAHULUAN}

Pupuk organik yang berkualitas banyak dikembangkan saat ini dari hasil inovasi teknologi dengan memanfaatkan limbah menjadi pupuk organik lengkap dengan unsur makro dan mikro yang langsung dapat dimanfaatkan oleh tanaman. Hasil penelitian menunjukkan bahwa pupuk organik merupakan penyangga biologi yang mempunyai fungsi dalam memperbaiki sifat fisik, kimia dan biologi tanah, sehingga tanah dapat menyediakan hara dalam jumlah yang berimbang. Perbaikan kondisi kesuburan tanah yang paling praktis adalah dengan penambahan pupuk organik ke tanah. Namun perlu juga diperhatikan keseimbangan kesuburan tanah sehingga pupuk yang diberikan dapat efektif dan efesien. Penambahan pupuk anorganik (pupuk sintetis) yang menyediakan ion mineral siap saji akan merusak kesuburan tanah dan fisik tanah, dimana tanah menjadi keras dan kompak.
Namun pemberian pupuk organik lebih lambat terurai menjadi ion mineral, apalagi jika aplikasi hanya berupa penambahan bahan organik mentah saja. Maka dari itu kandungan mikroorganisme tanah yang berperan untuk mempercepat dekomposisi bahan organik perlu diberikan agar kesuburan tanah terjaga (Dedik et al., 2017).

Untuk menjaga kesuburan tanah agar dapat meningkatkan produksi cabai salah satu cara mengatasinya yaitu dengan penggunaan mikroorganisme fungsional yang dikenal luas sebagai agensia hayati berupa pupuk biologis tanaman adalah jamur Trichoderma sp. Jamur Trichoderma sp. disamping berperan sebagai pengurai, dapat pula berfungsi sebagai agensia hayati dan stimulasi pertumbuhan tanaman. Beberapa Trichoderma sp. telah dilaporkan sebagai agensia hayati seperti Trichoderma harzianum, T. viridae,T. konigii dan $T$. asperellum yang 


\section{WIDYA BIOLOGI}

berspektrum luas pada berbagai tanaman pertanian. Biakan jamur Trichoderman sp. diberikan ke areal pertanaman dan berfungsi sebagai dekomposer dengan mendekomposisi limbah organik (dedaunan dan ranting tua) sebagai media tumbuh menjadi kompos yang bermutu (Dedik, et al., 2017).

Media tumbuh merupakan suatu bahan yang terdiri atas campuran nutrisi yang dipakai untuk menumbuhkan mikroorganisme baik dalam mengkultur jamur, bakteri, dan mikroorganisme lain. Suatu media dapat menumbuhkan mikroorganisme dengan baik diperlukan persyaratan antara lain: media diinkubasikan pada suhu tertentu, kelembapan harus cukup, $\mathrm{pH}$ sesuai, dan kadar oksigen cukup baik, media pembenihan harus steril, media tidak mengandung zat-zat penghambat, dan media harus mengandung semua nutrisi yang mudah digunakan mikroorganisme (Aini, 2015). Jamur dapat tumbuh baik pada media yang mengandung nutrisi yang dapat memenuhi syarat sebagai media pertumbuhan salah satunya dari sumber karbohidrat. Karbohidrat dan derivatnya merupakan substrat utama untuk metabolime karbon pada jamur. Karbon merupakan unsur yang paling penting karena $\quad 50 \% \quad$ berat mikroorganisme adalah karbon. Melimpahnya sumber di alam mendorong untuk menemukan variasi media pertumbuhan mikroorganisme perbanyakan massal. Melimpahnya sumber di alam mendorong untuk menemukan variasi media pertumbuhan mikroorganisme untuk perbanyakan massal. Diharapkan setelah mengetahui langkah-langkah perbanyakan massal jamur Trichoderma sp. petani dapat mempraktekkan dan mengaplikasikannya. Salah satu cara untuk meningkatkan kemampuan agen antagonis adalah menumbuhkannya/ memperbanyak pada media yang tepat. Oleh karenanyadiperlukan pelaksanaan programpengendalian terpadu sebagai upayastrategis, salah satunya berupa pemanfaatan Trichoderma sp.sebagai agensia hayati yang ramahlingkungan dan terjaganya kelestarian lingkungan serta pengelolaan sumberdaya alam yang berkelanjutan (Suanda dan Ratnadi, 2015). Disamping karakternya sebagai antagonis, diketahui pula bahwa Trichoderma sp. juga berfungsi sebagai decomposer dalam pembuatan pupuk organik. 


\section{WIDYA BIOLOGI}

Kemampuan Trichoderma sp. Trichoderma sp. dengan media tumbuh sebagai pengendali hayati,memberikan pengaruh positif terhadap perakaran tanaman, pertumbuhan tanaman dan produksi tanaman. Sifat ini menandakan bahwa Trichoderma sp. juga berperan sebagai Plant Growth Enhancer (Herlna dalam Dedik, 2017).Hormon auksin berupa IAA (Indole Asetic Acid) juga dihasilkan oleh $T$. virens yang berperan dalam pemanjangan sel-sel akar yang menyebabkan serapan hara semakin banyak dengan jangkauan serapan semakin luas. Serapan hara yang tinggi oleh akar tanaman mempengaruhi pertumbuhan tanaman karena nutrisi yang diperlukan tanaman terpenuhi, sehingga produksi tanaman juga semakin tinggi (Suanda, 2017a; Suanda dan Ratnadi, 2015).

Pertumbuhan vegetatif tanaman cabai besar (Capsicum frutescensL.) memerlukan ketersedian unsur hara yang cukup karena sangat diperlukan dalam pembentukan dan pertumbuhan sel-sel pada tanaman, selain faktor ketersediaan air, suhu dan iklim. Tanam cabai juga dapat tumbuh sehat jika tanah tempat tumbuhnya cukup tersedia hara makro dan mikro. Berdasarkan hal tersebut diharapkan penggunaan pupuk yang berbeda dapat dijadikan pupuk organik yang menguntungkan bagi petani.

Rumusan masalah dalam penelitian ini yaitu: apakah pupuk Trichoderma sp. yang dibiakan pada media tumbuh yang berbeda berpengaruh terhadap pertumbuhan vegetatif tanaman cabai besar (C. frutescensL.) dan pupuk Trichoderma sp. dari media tumbuh manakah yang paling baik untuk pertumbuhan vegetatif tanaman cabai besar (C. frutescensL.). Tujuan penelitian ini adalah untuk mengetahui adanya pengaruh pupuk Trichoderma sp. yang dibiakan pada media tumbuh yang berbeda terhadap pertumbuhanvegetatif tanaman cabai (C. frutescensL.) dan mengetahui pupuk Trichoderma sp. dari media tumbuh yang paling baik untuk pertumbuhan vegetatif tanaman cabai besar (C. frutescensL.).

\section{METODE PENELITIAN}

Penelitian ini tergolong jenis penelitian eksperimental yakni penelitian ini digunakan untuk mencari pengaruh perlakuan tertentu terhadap yang lain dalam kondisi yang terkendalikan (Sugiyono, 2016). Penelitian ini 


\section{WIDYA BIOLOGI}

dilaksanakan di Laboratorium Biologi dan Laboiratorium rumah kaca FPMIPA IKIP PGRI Bali dari bulan Februari sampai Mei 2018. Alat yang digunakan berupa cawan petri, autoclave, laminar air flow, jarum ose, lampu bunsen, neraca ohaus, mikropipet, pinset, sendok, timbangan, panci, baskom plastik,tabung reaksi, penggaris $30 \mathrm{~cm}$, polybag volume $3 \mathrm{~kg}$, alat dokumentasi/ kamera, kalkulator dan alat-alat tulis. Bahan yang digunakan, yaitu isolat murni Trichoderma sp. yang didapat dari isolat Trichoderma sp. penulis (Suanda, 2018), potato dextrose agarose (PDA), aquades, spirtus, alkohol, kertas tissu, alumunium foil, kain kasa, kantong plastik $2 \mathrm{~kg}$, kapas, kentang, umbi talas, ketela malem, singkong, jagung, dedak, bibit cabai varitas Megatop F1, polybag dan tanah kompos (pupuk tanah super yang dibeli di Toko Pertanian).

Perbanyakan Trichoderma sp. dilakukan secara in vitro (di laboratorium) pada media tumbuh $\mathrm{P} 0=$ kontrol tanpa pupuk Trichoderma sp.; P1 = pupuk Trichoderma sp. dari media umbi talas; $\mathrm{P} 2$ = pupuk Trichoderma sp. dari media singkong; P3 = pupuk Trichoderma sp. dari ketela malem; $\mathrm{P} 4=$ pupuk Trichoderma sp. dari media jagung dan P5 = pupuk Trichoderma sp. dari media kentang. Pengujian pupuk hayati dari Trichoderma sp. dilakukan secara in vivo (di rumah kaca). Kompos sebagai media tumbuh dari jamur Trichoderma sp. Yang akan diaplikasikan pada percobaan dirumah kaca, dibuat dari campuran jagung + dedak + Trichoderma sp. (perbandingan 50:10:1) (b/b/v),diinkubasi pada suhu $28^{\circ} \mathrm{C}$ selama 30 hari. Trichoderma sp. yang sudah tumbuh di media jagung dan dedak dicampur dengan tanah kompos yang telah disterilkan (perbandingan 1:50) (b/b), diinkubasi pada suhu $28^{\circ} \mathrm{C}$ selama 21 hari sehingga menjadi pupuk Trichoderma sp. (Suanda, 2017a). Setiap polybag ditanamami 3 bibit cabai, sehingga diperlukan 72 bibit cabai.

Data didapat dari pengukuran pertumbuhan vegetatif berupa tinggi tanaman dan jumlah daun tanaman cabai yang dilakukan setiap 7 hari yang dimulai umur 7 hari setelah tanam (HST) sampai tanaman cabai berumur 7 minggu setelah tanam (MST).Penelitian ini menggunakan Rancangan Acak Kelompok (RAK) yang perlakuannya masing-masing diulang sebanyak 4 kali. Setiap perlakuan diberikan $1.750 \mathrm{~g}$ tanah kompos $+250 \mathrm{~g}$ pupuk Trichoderma sp. 


\section{WIDYA BIOLOGI}

yang ditumbuhkan pada masing-masing media tumbuh dan perlakuan kontrol (P0) hanya diberikan $2.000 \mathrm{~g}$ tanah kompos. Penentuan jumlah perlakuan dan ulangan berpedoman pada ketentuan $(\mathrm{p}-1) \times(\mathrm{n}-1) \geq 15$ (Gomez and Gomez, 2007). Data dianalisis menggunakan analisis varians (Anova) dengan bantuan software SPSS for windows version 17.0 tahun 2009 dan uji beda rata-rata dilakukan menggunakan uji beda nyata terkecil (BNT) pada taraf 5\%.

\section{HASIL PENELITIAN DAN PEMBA- HASAN}

Pengaruh Pupuk Trichoderma sp. terhadap Tinggi Tanaman Cabai

Hasil analisis statistika pada pengamatan awal menunjukkan ratarata tinggi tanaman cabai antar perlakuan tidak berbeda nyata pada taraf $5 \%(\mathrm{P}>0,05)$. Tinggi tanaman cabai yang diaplikasikan pupuk Trichoderma sp. dari masing-masing media tumbuh sampai pengamatan umur 50 HST terus mengalami peningkatan dengan meninggalkan perlakuan kontrol (Tabel $1)$.

Tabel 1

Rata-rata tinggi tanaman cabai setiap 7hari setelah tanam (HST) (cm)

\begin{tabular}{|c|c|c|c|c|c|c|c|}
\hline $\begin{array}{c}\text { Pengamatan } \\
\text { (HST) }\end{array}$ & P0 & P1 & P2 & P3 & P4 & P5 & BNT 5\% \\
\cline { 2 - 8 } awal & $2,1 \mathrm{a}$ & $2,2 \mathrm{a}$ & $2,1 \mathrm{a}$ & $2,1 \mathrm{a}$ & $2,2 \mathrm{a}$ & $2,2 \mathrm{a}$ & \\
\hline 7 & 2,2 & 2,5 & 2,4 & 2,5 & 3,0 & 2,7 & \\
\hline 14 & 2,5 & 2,7 & 2,6 & 3,1 & 3,5 & 3,2 & \\
\hline 21 & 2,7 & 3,0 & 2,9 & 3,4 & 4,1 & 3,7 & \\
\hline 28 & 3,0 & 3,2 & 3,1 & 3,7 & 5,0 & 4,2 & \\
\hline 35 & 3,2 & 3,4 & 3,4 & 3,9 & 5,6 & 4,6 & \\
\hline 43 & 3,4 & 3,7 & 3,7 & 4,1 & 6,4 & 5,1 & \\
\hline 50 & $3,5 \mathrm{a}$ & $4,1 \mathrm{~b}$ & $3,9 \mathrm{~b}$ & $4,4 \mathrm{c}$ & $7,1 \mathrm{e}$ & $5,8 \mathrm{~d}$ & 0,331 \\
\hline
\end{tabular}

Keterangan: Angka-angka yang diikuti oleh huruf yang sama pada perlakuan dan baris yang sama adalah tidak berbeda nyata pada uji BNT 5\%.

Berdasarkan Tabel 1analisis 5\%) tinggi tanaman cabai pada sidik ragam pada uji beda nyata (BNT pengamatan minggu ke 7 (umur 50 


\section{WIDYA BIOLOGI}

HST) pada perlakuan pupuk

Trichoderma sp. dari media tumbuh umbi talas (P1) dan media tumbuh dari singkong (P2) menunjukkan tidak berbeda nyata pada taraf $5 \%(\mathrm{P}>0,05)$, tetapi dengan perlakuan Trichoderma sp. dari media tumbuh ketela (P3); media tumbuh jagung (P4) dan media tumbuh kentang (P5)menunjukkan berbeda nyata $(\mathrm{P}<0,05), \quad$ dimana perlakuan P5 memiliki pertumbuhan tinggi paling cepat. Hal ini menunjukkan bahwa aplikasi pupuk Trichoderma sp. dari masing-masing media tumbuh dapat meningkatkan pertumbuhan vegetatif berupa peningkatan tinggi tanaman cabai. Castro et al., (2009) menyatakan bahwaT. virens juga menghasilkan hormon auksin berupa IAA (IndoleAsetic Acid) yang berperan dalam pemanjangan sel-sel akar tanaman, sehingga menyebabkan terjadinya serapan hara semakin luas dan semakin tinggi.Hal ini terjadi karena Trichoderma sp. yang diaplikasikan bersama tanah kompos melindungi tanaman inang terhadap jamur patogen dan Trichoderma sp. memacupertumbuhan tanaman dengan menghasilkan hormon pertumbuhan.
Kondisi ini diduga karena jamur antagonis Trichoderma sp. memiliki mekanisme PGPF (Plant Growth Promoting Fungi) (Suanda, 2017a).

\section{Pengaruh Pupuk Trichoderma sp. terhadap Jumlah Daun Tanaman Cabai}

Hasil analisis statistika pada pengamatan awal menunjukkan rata-rata jumlah daun tanaman cabai antar perlakuan tidak berbeda nyata pada taraf $5 \%(\mathrm{P}>0,05)$. Jumlah daun tanaman cabai yang diaplikasikan pupuk Trichoderma sp. dari masing-masing media tumbuh sampai umur 50 HST terus mengalami peningkatan dengan meninggalkan perlakuan kontrol (Tabel 2).

Berdasarkan Tabel 2 analisis sidik ragam pada uji beda nyata (BNT $5 \%$ ) jumlah daun tanaman cabai pada pengamatan minggu ke 7 (umur 50 HST) pada perlakuan pupuk Trichoderma sp. perlakuan hanya tanah kompos sebagai kontrol (P0); pupuk Trichoderma sp. dari media tumbuh umbi talas (P1); media tumbuh singkong (P2) dan media tumbuh ketela malem menunjukkan tidak berbeda nyata pada taraf 5\% (P>0,05), tetapi dengan perlakuan Trichoderma sp. dari media tumbuh jagung (P4) dan 


\section{WIDYA BIOLOGI}

media tumbuh kentang (P5)

menunjukkan berbeda nyata $(\mathrm{P}<0,05)$.

Tabel 2

Rata-rata jumlah daun tanaman cabai setiap 7 hari setelah tanam (HST) (helai)

\begin{tabular}{|c|c|c|c|c|c|c|c|}
\hline $\begin{array}{c}\text { Pengamatan } \\
(\text { HST })\end{array}$ & \multicolumn{7}{|c|}{ Perlakuan } \\
\cline { 2 - 8 } awal & $2,8 \mathrm{a}$ & $2,7 \mathrm{a}$ & $2,8 \mathrm{a}$ & $2,7 \mathrm{a}$ & $2,8 \mathrm{a}$ & $2,8 \mathrm{a}$ & \\
\hline 7 & 2,8 & 2,8 & 2,8 & 2,7 & 3,3 & 3,3 & \\
\hline 14 & 3,0 & 3,6 & 3,5 & 3,7 & 4,0 & 4,0 & \\
\hline 21 & 2,9 & 3,9 & 4,0 & 3,9 & 4,5 & 4,6 & \\
\hline 28 & 3,1 & 3,9 & 4,3 & 4,1 & 4,8 & 5,2 & \\
\hline 35 & 3,0 & 3,9 & 3,8 & 4,1 & 5,0 & 5,3 & \\
\hline 43 & 3,3 & 3,9 & 3,8 & 3,8 & 5,6 & 4,9 & \\
\hline 50 & $3,4 \mathrm{a}$ & $3,7 \mathrm{a}$ & $3,6 \mathrm{a}$ & $3,9 \mathrm{a}$ & $6,0 \mathrm{~b}$ & $4,8 \mathrm{~b}$ & 0,592 \\
\hline
\end{tabular}

Keterangan: Angka-angka yang diikuti oleh huruf yang sama pada perlakuan dan baris yang sama adalah tidak berbeda nyata pada uji BNT 5\%.

Hal ini menunjukkan bahwa aplikasi pupuk Trichoderma sp. dari masingmasing media tumbuh dapat meningkatkan pertumbuhan vegetatif berupa penambahan jumlah daun tanaman cabai. Terjadinya perbedaan pertumbuhan vegetatif tanaman cabai pada masing-masing perlakuan media tumbuh dari Trichoderma sp. kemungkinan disebabkan oleh ketersediaan nutrisi untuk pertumbuhan dan perkembangbiakan jamur Trichoderma sp. pada media tumbuh tersebut. Data pada Tabel 1 dan Tabel 2 perlakuan Trichoderma sp. yang dibiakan pada media tumbuh jagung menunjukkan pertumbuhan vegetatif tanaman cabai besar paling baik. Berdasarkan hasil penelitian Rahmadani (2016) bahwa perbanyakan Trichoderma sp. pada media jangung yang relatif memberikan hasil lebih baik. Hal ini disebabkan jagung mudah ditumbuhi oleh Trichoderma sp., karena media jagung memiliki kamdungan amilum yang sangat banyak dan jagung mengandung berbagai nutrisi yang diperlukan untuk pertumbuhan jamur. 


\section{WIDYA BIOLOGI}

Menurut Yulfa (2017) jagung memiliki kandungan antara lain: protein (10\%), minyak/lemak (4\%), karbohidrat $(70,7 \%)$,dan vitamin. Sedangkan komposisi kimia jagung : air (15,5\%), Nitrogen $(0,75 \%)$, Abu $(4,37 \%), \mathrm{K}_{2} \mathrm{O}$ $(1,64 \%), \mathrm{N}_{\mathrm{a} 2} \mathrm{O}(0,05 \%)$ dan $\mathrm{CaO}(0,49 \%)$ sehingga dapat digunakan sebagai sumber bahan makanan untuk pertumbuhan mikroorganisme (Yulfa, 2017). Bakman et al., 2001 dalam Handiyati et al., 2005 menyatakan untuk menghasilkan jamur yang berkualitas maka diperlukan media yang optimal artinya dapat menyediakan nutrisi yang diperlukan jamur untuk pertumbuhan dan perkembangannya disamping kondisi lingkungan yang optimal.

Beberapa jenis media yang telah terbukti mampu mengaktivasi pertumbuhan Trichoderma sp. adalah jagung, kentang, bekatul, beras, jerami padi, campuran dedak dengan serbuk gergaji, campuran sekam padi dengan sekam gandum (Sinaga, et al.,; 1989, dalam Nurbalis, 2010). Untuk dapat digunakan sebagai sumber nutrisi yaitu sumber karbon, senyawa karbohidrat harus dihirolisis lebih dahulu oleh enzim selulose menjadi glukosa atau selubiosa. Menurut Schmidt (2006) Trichoderma merupakan jamur selulolitik memiliki potensi yang baik mendekomposisi selulosa dan hemiselulosa dibandingkan lignin. Hal ini juga dilaporkan oleh Samingan (2009) bahwa Trichoderma harzianum mampu mendekomposisi selulosa lebih tinggi dibandingkan lignin.Glukosa ini yang dibutuhkan dalam pertumbuhan konidia Trichoderma sp.Kandungan karbohidrat yang tinggi akan memacu pertumbuhan konidia Trichoderma sp, dimana konidia tersebut akan menjadi kecambah konidia yang akan terus berkembangbiak (Wijaya et al., 2012).

Hasil penelitian Balai Pengkajian dan Pengembangan Teknologi (2002) melaporkan bahwa Trichoderma sp. ternyata juga memberikan pengaruh positif pada pertumbuhan vegetatif dan perkembangan generative tanaman serta hasil panen. Novizan, (2002) menyebutkan Trichoderma sp. selain bermanfaat sebagai agensia hayati yang bersifat antagonis terhadap jamur patogen tular tanah dan juga bersifat dekomposer dalam mempercepat proses pembuatan kompos.Seiring bertambahnya umur tanaman, maka keberadaan jamur Trichoderma sp. 
mampu menunjukkan sebagaipenghambatan terhadap patogen dan memberikan kemudahan kepada tanaman inang dalam menyerap unsur hara (Shoresh et al., 2005).

Hasil penelitian Suanda (2017a) menyebutkan bahwa penggunaan agensia hayati Trichoderma sp. mampu menyediakan unsur hara bagi tanaman tomat, untuk mendukung pertumbuhan vegetatif melalui proses dekomposisi bahan organik yang diberikan pada media tanam. Trichoderma sp. dapat memberikan pengaruh positif yang nyata terhadap jumlah daun bibit cengkeh, karena antagonis Trichoderma sp. ini sangatefektif dan berkembang dengan baik di sekitar perakaran bibit cengkeh dalam polybag, sehingga terjadi simbiosis mutualisme antara jamur antagonis dengan tanaman inang (Suanda, 2017b). Pernyataan ini juga didukung oleh pendapat Agrios (2005), yang melaporkan bahwa tanaman inang yang diaplikasikan biokontrol akan bereaksi terhadap patogen yang menyerangnya, sehingga memungkinkan terjadi perubahan fisiologi tanaman inang, seperti: respirasi, fotosintesis dan translokasi, transpirasi, pertumbuhan serta perkembangan menjadi lebih baik.

\section{SIMPULAN}

Berdasarkan hasil analisis dan pembahasan, maka dapat diambil suatu simpulan yaitu ada pengaruh pemberian pupuk Trichoderma sp. dari media yang berbeda terhadap pertumbuhan vegetatif tanaman cabai besar (C. frutescens L.). Perlakuan pupuk Trichoderma sp. dari media tumbuh jagung (P4) yang paling baik untuk meacu pertumbuhan vegetatif tanaman cabai besar dengan rata-rata tinggi tanaman $7,1 \mathrm{~cm}$ dan rata-rata jumlah daun 6,0 pada pengamatan umur 50 HST.

\section{SARAN}

Perlu diadakan penelitian lebih lanjut di lapangan agar hasil penelitian ini dapat diaplikasikan ke masyarakat dalam usaha budidaya tanaman cabai besar (Capsicum frutescensL.) pada konsentrasi yang optimal dan juga diujikan pada tanaman yang berbeda untuk mengurangi penggunaan pupuk anorganik atau pupuk sintetis.

\section{DAFTAR PUSTAKA}

Aini, N. 2015. Media Alternatif Untuk Pertumbuhan Jamur Menggunakan Sumber Karbohidrat Yang Berbeda. Pendidikan Biologi. 


\section{WIDYA BIOLOGI}

Universitas Muhamma-diyah Surakarta.

Agrios, G.N. 2005. Plant Pathology. Departement of Plant Pathology University of Florida. Elsevier Academic Press, New York, $5^{\text {th }}$ ed. 398-399.

Balai Pengkajian dan Pengembangan Teknologi (BPPT). 2002. Biopestisida Trichoderma sp. Teknologill. Suara Merdeka. edisi 25 Maret.

Castro, Ortiz, R.H.A., Cornejo, C.L., Rodriguez. M. and Bucio, J.L. 2009. The role of microbial signals in plant growth ang development. Journal Plantsignaling \& Behavior;;4 (8): 701-712.

Clay, K. 1996. Interactions among fungal endophytes, grasses and herbivores. Journal Researcheson Populations Ecology; 38 (2): 191201.

Dedik, S., Artha, N., Wirya, S. 2017. Efektifitas Pemberian Kompos Trichoderma Sp. Terhadap Pertumbuhan Tanaman Cabai (Capsicum annum L.). Jurnal Agroekoteknologi Tropika.; 6 (1). Fakultas Pertanian Universitas Udayana.

Gomez, K.A dan Gomez, A.A. 2007. Prosedur Statistik untuk Penelitian Pertanian. Edisi kedua. Penerbit Universitas Indonesia (UI-Press)

Hamdiyati Y. 2005. Serbuk Gergaji Kayu dan Biji Jagung sebagai Media dalam Pembuatan Bibit Induk.
Novizan. 2002. Membuat dan Memanfaatkan Pestisida Ramah Lingkungan. Jakarta: Agromedia Pustaka.

Nurbalis. 2010. Pemanfaatan Jerami Padi Sebagai Medium Perbanyakan Trichoderma harzianum dan Aplikasinya Pada Tanaman Cabai. Sumatra Barat.

Rahmadani, R. 2016. Perbanyakan Trichoderma sp. Pada Beberapa Media di Laboratorium.Sekolah Tinggi Ilmu Pertanian Agrobisnis Perkebunan Medan.

Suanda, I.W. dan Delly, N.M.R. 2018. Eksplorasi dan Uji Antagonis Trichoderma sp. terhadap Jamur Patogen Penyebab Penyakit Rebah Kecambah (Sclerotium rolfsii Sacc.) pada Tanaman Tomat secara In Vitro.Buletin Teknologi Pertanian. Balai Pengkajian Teknologi Pertanian (BPTP) Bali Badan Penelitian dan Pengembangan Pertanian Kementerian Pertanian; 16 (47): 7 12.

Suanda, I.W. 2017a. Pemanfaatan Trichoderma sp. sebagai Agensia Hayati Ramah Lingkungan dalam Pengendalian Penyakit Fusarium pada Tanaman Tomat (Lycopersicum esculentum Mill.) Prosiding Seminar Nasional Penguatan dan Pengajaran Biologi sebagai Ilmu Dasar FMIPA Universitas Hindu Indonesia. Denpasar.p.390-398. (URL : http://www.unhi.ac.id/wpcontent/u ploads/2017/05/ProsidingLengkap2.pdf). 


\section{WIDYA BIOLOGI}

Suanda, I.W. 2017b. Identifikasi Patogen Penyakit Akar Putih pada Tanaman Cengkeh (Syzygium aromaticum $\mathrm{L}$.) dan Pengendalian secara Hayati (Disertasi). Fakultas Pertanian Universitas Udayana.

Suanda, I.W. dan Ratnadi, N.W. 2015.Daya Antagonisme Trichoderma sp. Lokal terhadap Jamur Patogen Penyebab Penyakit Rebah Kecambah (Sclerotium rolfsii Sacc.) pada Tanaman Tomat (Lycopersicum esculentum MILL.). Denpasar. J. Emasains. FPMIPA IKIP PGRI Bali; IV (2): 155-162.

(URL:http://repository.ikippgribali.ac.id/33/1/ArtikelDayaHambatTricho derma.pdf).

Sugiyono. 2016. Metode Penelitian Kuantitatif, Kualitatif, dan Kombinasi (Mix Methods). Bandung: Penerbit Alfabeta.

Shoresh, M., Yedidia, I. and Chet, I. 2005.Involvement of Jasmonic Acid/Ethylene Signaling Pathway in the Systemic Resistance Induced in Cucumber by Trichoderma asperellum T203. Department of Biological Chemistry. The Weizmann Institute of Science. Rehovot 76100. Israel. Journal Biological Control; 95 (1): 76-84.

Samingan. 2009. Suksesi fungi dan dekomposisi serasah daun Acacia mangium Willd dalam kaitan dengan keberadaan Ganoderma dan Trichoderma di lantai hutan akasia (disertasi). Bogor. Sekolah Pascasarjana Institut Pertanian Bogor.
Schmidt, O. 2006. Wood and Tree Fungi. Biology, Damage, Protection, and Use. Berlin: Springer.

Wijaya, I.; Oktarina dan Virdanuriza, M. 2012. Pembiakan Massal Jamur Trichoderma sp. pada Beberapa Media Tumbuh sebagai Agensia Hayati Pengendalian Penyakit Tanaman. Fakultas Pertanian Universitas Muhammadiyah Jember.Agritrop Jurnal Ilmu-Ilmu Pertanian. p. 87-91.

Yulfa, S. 2017. Pertumbuhan Trichoderma sp. pada berbagai media padat. Available: http://yulfasari.blogspot.co.id/201 7/01/pertumbuhan-trichoder-sppada-berbagai.html. (Diunduh pada tanggal 6 juni 2018). 
Volume 01 Nomor 01 Maret 2019

P ISSN : 2086-5783

WIDYA BIOLOI

E ISSN : 